\title{
Strategi Pengembangan Obyek Wisata Religi Bukit Surowiti di Kecamatan Panceng, Gresik
}

\author{
"Tisa Angelia, Eddy Imam Santoso \\ Departemen Arsitektur Fakultas Teknik Universitas Merdeka Surabaya \\ *e-mail: tisaangelia78@gmail.com
}

\section{INFO ARTIKEL}

\section{Riwayat Artikel:}

Diterima: 10-09-2019

Disetujui: 20-11-2019

\section{Kata Kunci: \\ Bukit Surowiti Strategi Pengembangan Wisata Religi}

\begin{abstract}
ABSTRAK
Abstrak: Kabupaten Gresik merupakan kawasan industri yang juga menjadi salah satu tujuan wisata terkenal di Jawa Timur dengan beragam potensi wisatanya, yaitu wisata alam, wisata budaya dan wisata religi. Obyek wisata religi tersebut antara lain wisata wali yaitu makam Sunan Giri dan Maulana Malik Ibrahim. Wisata Sunan Giri dan Maulana Malik Ibrahim merupakan dua obyek wisata religi yang banyak dikunjungi wisatawan dan menjadi ikon Kota Gresik sebagai Kota Wisata Wali. Wisata Bukit Surowiti adalah salah satu obyek wisata di Gresik yang terdiri dari obyek wisata religi berupa makam dan petilasan pemuka agama islam, serta wisata alam berupa gua. Namun dalam perkembangannya Wisata Bukit Surowiti yang berdekatan dengan Wisata Bukit Jamur dan Wisata Pantai Dalegan belum optimal pengelolaan dan promosinya. Penelitian ini bertujuan untuk mengetahui potensi Wisata Bukit Surowiti dan selanjutnya merumuskan strategi pengembangan wisata religi. Penelitian ini menggunakan metode penelitian eksploratif dengan teknik analisis SWOT. Penelitian eksploratif dilakukan dengan mencari dan menghimpun informasi untuk merumuskan suatu hipotesis. Adapun hasil penelitian terkait faktor-faktor kekuatan dan peluang yang antara lain adalah potensi alam dan peninggalan leluhur berupa petilasan dan makam pemuka islam, serta keberadaan wisata religi yang sudah terkenal seperti Wisata Wali Sunan Giri dan Maulana Malik Ibrahim, wisata alam seperti Wisata Bukit Jamur dan Wisata Pantai Dalegan di Gresik, faktor-faktor kelemahan diantaranya kondisi sanitasi, pengadaan air bersih dan aksesibilitas yang kurang baik, dan faktor ancaman yaitu kurangnya dukungan masyarakat dan pemerintah, serta perkembangan industri yang semakin pesat di Gresik. Selanjutnya faktor-faktor tersebut diharapkan dapat menjadi acuan dan kontribusi untuk pemerintah setempat dalam merumuskan strategi pengembangan wisata religi di Bukit Surowiti.
\end{abstract}

\begin{abstract}
Gresik Regency is an industrial area which is also one of the famous tourist destinations in East Java with a variety of tourism potentials, namely natural tourism, cultural tourism and religious tourism. Religious tourism objects include guardian tourism namely the tomb of Sunan Giri and Maulana Malik Ibrahim. Sunan Giri and Maulana Malik Ibrahim tourism objects are two religious tourism objects that are visited by many tourists and become icons of Gresik City as Wali Tourism City. Surowiti Hill Tourism is one of the attractions in Gresik which consists of religious tourism objects in the form of tombs and religious leaders, and natural attractions such as caves. However, in its development, Bukit Surowiti Tourism which is adjacent to Bukit Mushroom Tourism and Dalegan Beach Tourism has not been optimal in its management and promotion. This study aims to determine the potential of Surowiti Hill Tourism and then formulate a strategy for developing religious tourism. This research uses exploratory research methods with SWOT analysis techniques. Explorative research is carried out by searching and gathering information to formulate a hypothesis. The results of research related to strength factors and opportunities include natural potentials and ancestral relics in the form of Islamic leaders and graves, as well as the existence of well-known religious tourism such as Wali Sunan Giri and Maulana Malik Ibrahim Tourism, nature tourism such as Bukit Jamur Tourism and Dalegan Beach Tourism in Gresik, weakness factors include sanitation conditions, clean water supply and poor accessibility, and threat factors namely lack of community and government support, as well as the rapid development of industry in Gresik. Furthermore, these factors are expected to be a reference and contribution to the local government in formulating a strategy for developing religious tourism in Bukit Surowiti.
\end{abstract}




\section{A. LATAR BELAKANG}

Pariwisata dunia saat ini semakin berkembang pesat di negara-negara selain negara barat, hal ini bisa dilihat dengan adanya dominasi negara-negara di Asia Pasifik, Timur Tengah dan negara-negara CIS sebagai penghasil turis internasional (Cetin \& Dincer, 2016). Beberapa negara di Asia seperti Jepang, Korea Selatan dan Thailand sedang berupaya untuk mempromosikan pariwisata dengan menggunakan strategi wisata halal, baik dalam makanan, restaurant, maupun fasilitas untuk para wisatawan muslim. Secara statistik dan industri pariwisata dunia diketahui bahwa perkembangan pasar wisatawan muslim dunia semakin cepat berkembang dengan perkiraan wisatawan muslim di tahun 2015 yaitu 117 juta wisatawan menjadi 168 juta di tahun 2020 (Yousaf \& Xiucheng, 2018). Wisata halal dapat dilihat sebagai prospek yang menjanjikan untuk bisnis wisata dunia termasuk di Negara Indonesia (Djakfar, 2017). Jumlah penduduk muslim di Indonesia sebagai negara dengan mayoritas penduduk muslim terbesar di dunia adalah 207.176.162 (BPS, 2010), menjadi peluang besar bagi pariwisata syariah yang menggabungkan konsep wisata dan tata nilai agama islam untuk dikembangkan di negara ini (Widagdyo, 2015).

Perkembangan pariwisata di Indonesia menunjukkan semakin dikenalnya wisata halal di kalangan wisatawan muslim, sehingga berbagai daerah di Nusantara berlomba-lomba melakukan pembaharuan konsep pariwisatanya menjadi konsep wisata halal (Firdausia Hadi and M. Khoirul Hadi al-Asy Ari, 2017). Konsep wisata halal/halal tourism dalam penerapannya tidak dibatasi hanya untuk wisatawan muslim saja, melainkan untuk semua wisatawan baik domestik maupun asing. Wisata religi islam merupakan penerapan konsep wisata halal yang semakin menunjukkan kemampuannya dalam meningkatkan devisa negara dan perekonomian masyarakat, khususnya pendapatan masyarakat sekitar lokasi wisata. Wisata religi merupakan salah satu jenis produk wisata merupakan jenis wisata yang mempunyai tujuan memenuhi kebutuhan rohani manusia dalam memperkuat iman dengan mendatangi tempat-tempat yang dianggap memiliki nilai religius (Anwar dan Hamid, 2017).

Wisata religi di Indonesia dikenal dari beberapa kalangan seperti, penyedia jasa angkutan wisata, pengelola dan penjaga kawasan makam para wali, pemuka masyarakat dan masyarakat secara luas. Wisata religi di Indonesia tercipta dengan adanya beberapa daerah yang memiliki potensi dari aspek religiositas, seperti area wisata yang dihuni oleh pemeluk Islam yang taat dan kuat sehingga tema keislaman dapat menjadi ikon spesifik sebagai tujuan wisata yang syariah (Djakfar, 2017). Sebagai salah satu tujuan wisata dunia yang dikenal dengan banyaknya wisata religi, Indonesia memiliki beberapa daerah yang menerapkan konsep wisata halal, Seperti di Sumatra Barat, Riau, Lampung,
Banten, Jakarta, Jawa Barat, Jawa Timur, Makassar, dan Lombok (ASDHIANA DALAM SUHERLAN, 2015).

Kabupaten Gresik yang berada di wilayah Provinsi Jawa Timur merupakan salah satu daerah yang dikenal dengan wisata religinya, bahkan Kota Gresik yang meiliki banyak pesantren dan beberapa wisata religi yang ada disebut juga sebagai kota santri. Beberapa wisata religi yang terkenal di Kabupaten Gresik antara lain adalah Makam Sunan Giri dan Maulana Malik Ibrahim, selain itu terdapat pula wisata religi yang potensial yaitu kawasan wisata religi Bukit Surowiti di Kecamatan Panceng yang memiliki beberapa obyek wisata, seperti Petilasan Sunan Kalijaga dan beberapa makam pemuka agama islam, di kawasan ini juga terdapat obyek wisata alam dan gua.

Wisata Bukit Surowiti dengan fenomena alamnya yaitu berupa gua karts berpotensi dikembangkan karena letaknya berdekatan dengan obyek Wisata Bukit Jamur dan Pantai Pasir Putih Dalegan. Kawasan wisata memiliki pemandangan alam yang sangat menarik dengan lokasi wisata berada di atas bukit yang terjal. Obyek wisata Bukit Surowiti dengan beberapa obyek wisatanya dan lokasi yang jauh dari pusat kota memiliki daya tarik tersendiri bagi wisatawan yang berkunjung ke lokasi obyek wisata ini, hal ini ditunjukkan dengan semakin meningkatnya jumlah pengunjung dari tahun ke tahun, yaitu tahun 2008 jumlah pengunjung 4.814, tahun 2009 jumlah pengunjung 6.540, tahun 2010 jumlah pengunjung 14.890, dan tahun 2011 jumlah pengunjung 18.780 (Syafik, 2013). Namun peningkatan jumlah wisatawan yang datang ke obyek wisata ini tidak tersebar secara merata di kawasan obyek wisata. Sehingga beberapa kondisi obyek-obyek wisata yang ada di Bukit Surowiti tidak berkembang secara optimal.

Wisata religi sebagai bagian dari wisata halal (halal tourism) merupakan konsep wisata yang saat ini banyak diminati oleh wisatawan dan sangat strategis karena sektor ini merupakan sektor andalan yang nantinya diharapkan akan dapat meningkatkan kesejahteraan masyarakat disekitar lokasi wisata melalui potensi obyek wisata serta keterlibatan masyarakat, khususnya dalam pengembangan wisata di Gresik (Ade, 2016). Partisipasi masyarakat dalam pengembangan wisata akan memberikan dampak positif. Keterlibatan masyarakat lokal dari segi lingkungan maupun ekonomi akan dapat menjaga sumberdaya yang ada dan meningkatkan nilai jual kawasan beserta investasinya (Fandeli, 2001). Untuk dapat mengoptimalkan obyek wisata Bukit Surowiti sebagai kawasan wisata religi maupun alam perlu dilakukan pengkajian untuk mengetahui potensi, permasalahan, strategi pengelolaan berkelanjutan. Selain itu perlu mengetahui nilai strategis dari keberadaan obyek wisata religi yang bermanfaat bagi masyarakat sekitar salahsatunya melalui kegiatan pengembangan wisata religi dengan upaya konservasi, proses pemberdayaan masyarakat dan kegiatan rekreasi yang terintegrasi dengan baik. 


\section{B. METODE PENELITIAN}

Sumber data pada penelitian ini terbagi dua, yaitu sumber data primer dan sumber data sekunder. Metode pengumpulan data primer dilakukan dengan observasi (pengamatan langsung) di lapangan. Observasi yang dilakukan dalam penelitian ini adalah observasi terstruktur yang sistematik, dimana dalam hal ini peneliti telah mengetahui aspek-aspek apa saja yang relevan dengan masalah dan tujuan penelitian. Observasi terstruktur ini dengan mempersiapkan pedoman pengamatan secara detail dan menyediakan tabel cek list yang digunakan sebagai pedoman pengamatan (Supriharjo, 2013:III-3).

Pengumpulan data sekunder adalah dengan studi literatur dan telaah dokumen. Studi literatur terkait beberapa hasil studi terdahulu mengenai pengelolaan wisata religi dan pengembangan wisata Bukit Surowiti Kecamatan Panceng. Pengumpulan data juga dilakukan melalui wawancara yang dibantu kuisioner. Kuisioner ini sebelumnya telah diuji validitasnya kepada responden di kawasan wisata religi Bukit Surowiti Kecamatan Panceng, Gresik.

Pengunjung yang diwawancarai sebanyak 25 orang yang berasal dari 50\% jumlah rata-rata pengunjung selama satu minggu. Kriteria pengunjung yang diwawancarai adalah yang berusia diatas 17 tahun dengan pendidikan minimal Sekolah Menengah Pertama (SMP). Responden dari masyarakat local sebanyak 2 orang, yaitu masyarakat yang sehari-hari selalu berpartisipasi aktif dalam pengelolaan obyek wisata Bukit Surowiti. Selain itu juga terdapat 1 responden dari pihak pengelola (Dinas Pariwisata setempat) yang kesehariannya aktif mengelola obyek wisata religi.

Hasil dari identifikasi potensi wisata diintegrasi dengan persepsi serta partisipasi responden dalam menunjang alternatif strategi pengembangan wisata religi. Selanjutnya hasil tersebut dianalisis dengan bantuan analisa Strength, Weakness, Opportunity, Thread (SWOT) (Rangkuti, 2005) dengan menganalisis faktor internal dan eksternal kawasan wisata religi Bukit Surowiti. Analisa SWOT akan dapat membantu dalam upaya menentukan alternatif strategi pengembangan wisata religi di Bukit Surowiti Kecamatan Panceng, Gresik.

\section{HASIL DAN PEMBAHASAN}

\section{Kondisi Eksisting Potensi Wisata Religi Kabupaten Gresik}

Gresik adalah kota industri yang terus berkembang, pabrik dan pergudangan semakin meluas sampai ke pinggiran kota diantaranya Kawasan Industri Gresik (KIG). Selain dikenal sebagai kota industri, Gresik juga dikenal sebagai kawasan pariwisata religi karena memiliki banyak pesantren dan beberapa wisata religi. Wisata religi Islam di Kabupaten Gresik tersebar ke beberapa wilayah di Gresik, diantaranya seperti obyek wisata Sunan Giri dan Maulana Malik Ibrahim yang dikenal dengan obyek wisata Wali yang dikunjungi ribuan wisatawan setiap harinya.

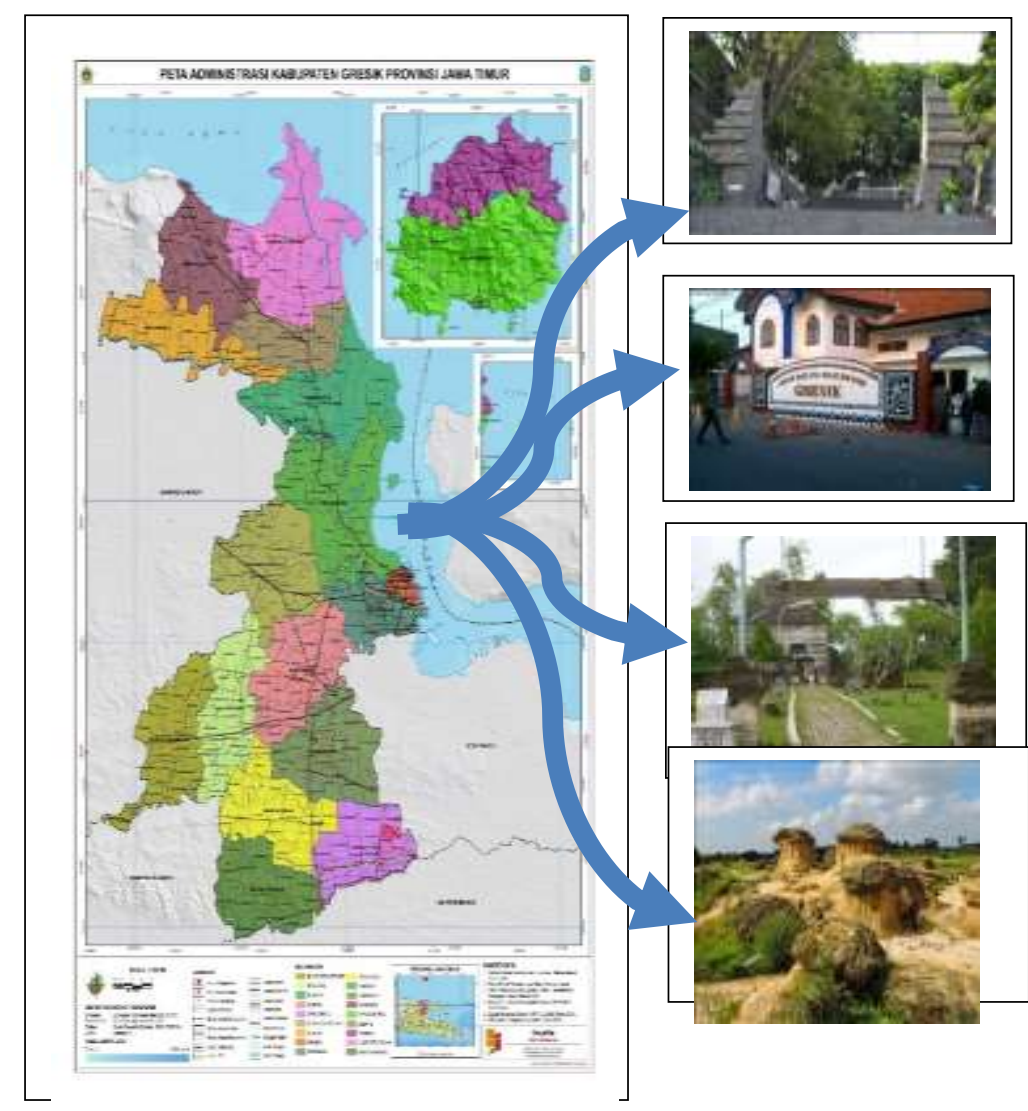

Gambar 1. Beberapa obyek wisata Kab.Gresik
Obyek Wisata Sunan Giri

Obyek Wisata

Maulana Malik Ibrahim

Obyek Wisata

Fatimah Binti Maimun

Obyek Wisata

Bukit Jamur 


\section{Sub Kondisi Eksisting Obyek Wisata Religi Bukit Surowiti}

Desa Surowiti terletak di Kecamatan Panceng, tepatnya dibagian utara Kabupaten Gresik. Kecamatan Panceng merupakan wilayah yang berada di ketinggian \pm $3 \mathrm{~m}$ di atas permukaan laut dan berjarak kurang lebih 40 $\mathrm{km}$ dari Kota Gresik. Walaupun jarak yang jauh dari pusat kota, kecamatan ini memiliki potensi wisata yang sangat potensial, seperti obyek Wisata Pasir Putih Dalegan, obyek Wisata Bukit Jamur, dan obyek Wisata Bukit Surowiti. Kawasan Bukit Surowiti adalah sebuah perkampungan kecil yang lokasinya diatas bukit seluas kurang lebih 5 ha dengan ketinggian $260 \mathrm{~m}$ dari permukaan laut, dengan jumlah penduduk \pm 200 kepala keluarga. Lokasi desa ini berada di atas bukit yang terjal dan untuk mencapai puncak bukit dilalui dengan sarana jalan beraspal serta anak tangga yang berjumlah sekitar 300 anak tangga. Aksesibilitas menuju permukiman Desa Sorowiti dapat dilihat pada gambar 3.

Wisata Bukit Surowiti menawarkan tujuh obyek wisata yang tersebar di seluruh kawasan ini, dan terbagi menjadi obyek wisata religi dan obyek wisata alam. Obyek wisata religi, yaitu : Petilasan Sunan Kalijaga, Makam Mbah Singo, Makam Mpu Supa, Makam Raden Bagus Mataram, sedangkan obyek wisata alam, yaitu Gua Langsih, Gua Macan, Gua Lumbung. Pilihan obyek wisata di bukit Sorowiti dapat dilihat di gambar 4.

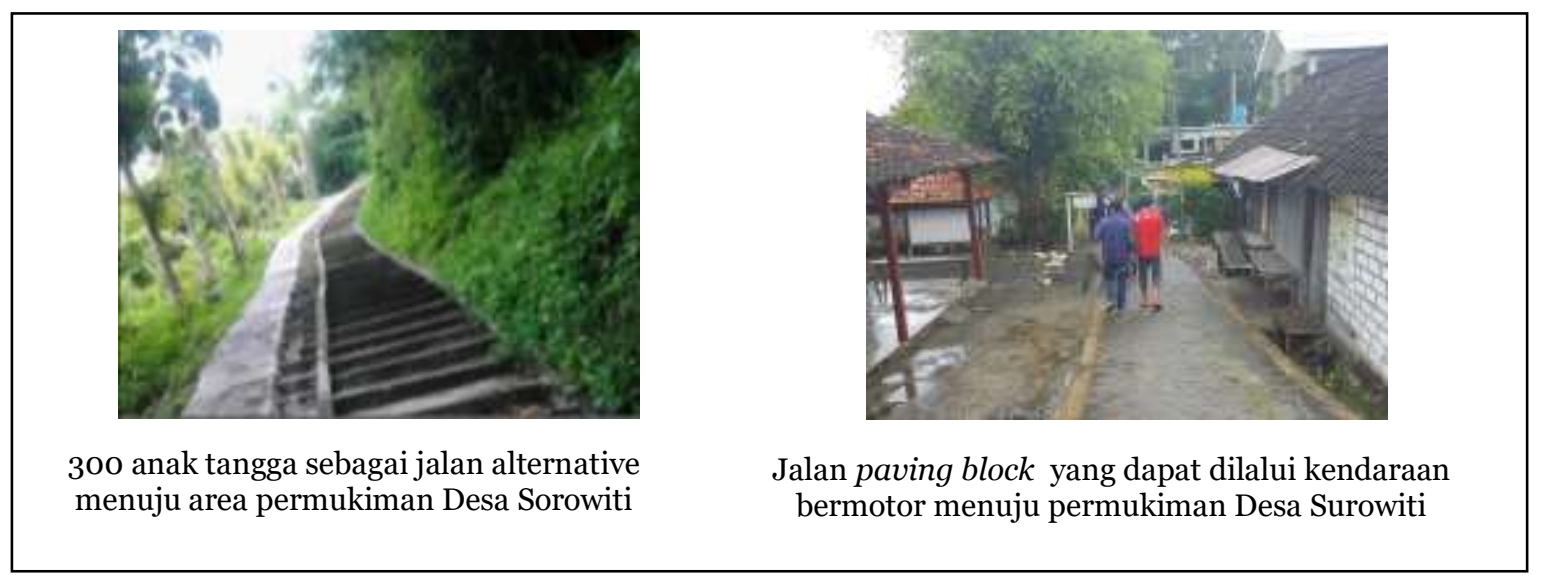

Gambar 3. Kondisi aksesibilitas Desa Surowiti

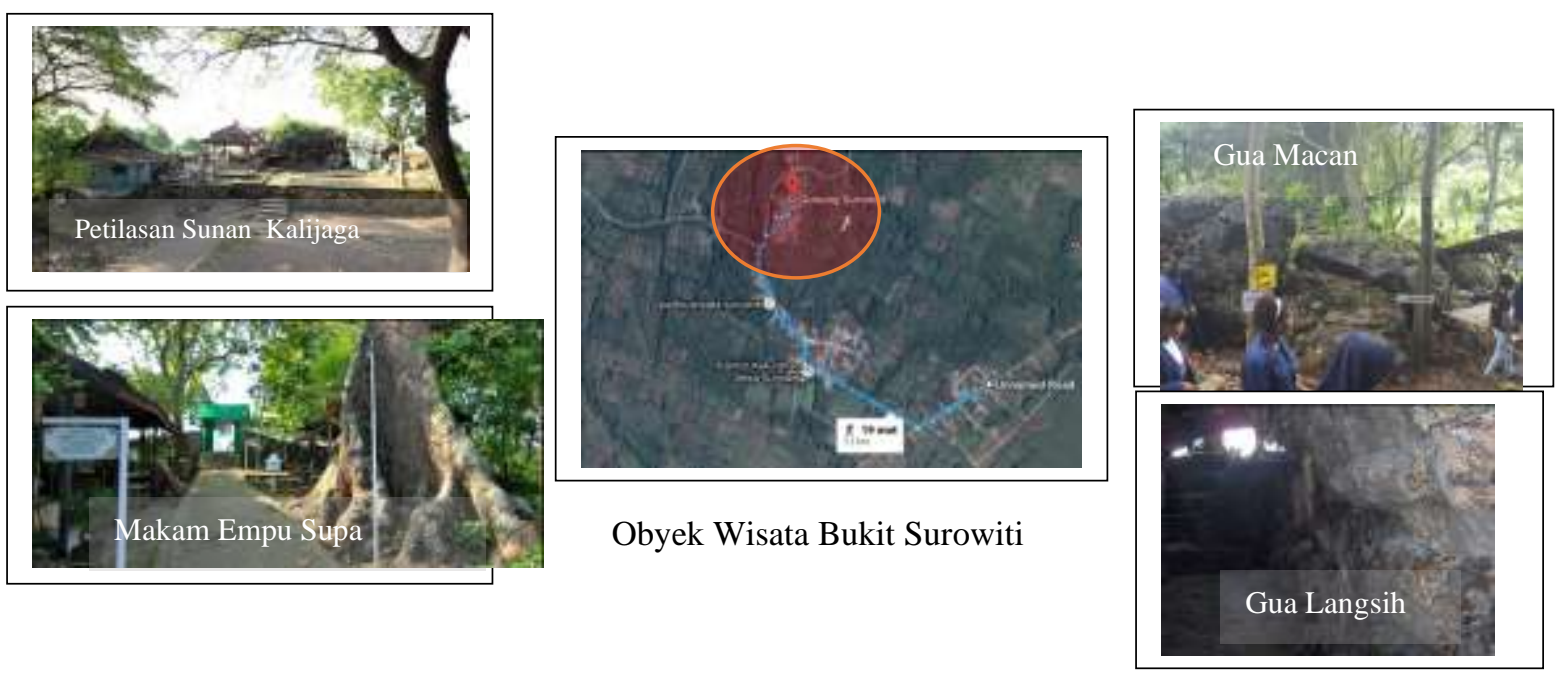

Gambar 4. Beberapa Obyek Wisata Di Bukit Surowiti 
Bukit Surowiti dengan beragam obyek wisata yang ada didalamnya, memiliki daya tarik tersendiri bagi para pengunjung yang datang ke bukit ini, berdasarkan data yang didapat dari pengelola obyek wisata ini, yaitu Kelompok Sadar Wisata Desa Surowiti pengunjung terus meningkat dari tahun ketahun. Namun peningkatan jumlah pengunjung yang datang ke obyek wisata Bukit Surowiti belum diimbangi dengan sarana prasarana yang cukup baik. Sarana prasarana yang ada di obyek wisata Bukit Surowiti masih belum memadai untuk mendukung pengembangan wisata yang ada, seperti halnya pengadaan air bersih.

Survey yang dilakukan untuk mengetahui bagaimana pengadaan air bersih menunjukkan bahwa air bersih sangat susah didapatkan. Air bersih yang digunakan sehari-hari didapatkan dari sumur yang berada di kaki bukit, sehingga masyarakat harus bergantian turun kebawah bukit untuk mengambil air bersih. Kondisi sanitasi tidak jauh berbeda dengan kondisi air bersih di kawasan obyek wisata ini, hanya terdapat satu kamar mandi umum yang dapat digunakan oleh pengunjung obyek wisata Bukit Surowiti. Kondisi saluran air hujan (drainase) yang ada disekitar lingkungan permukiman penduduk Bukit Surowiti masih belum terintegrasi dengan baik antara satu perumahan dengan perumahan yang lain, bentuk fisik saluran drainase belum seluruhnya dibangun dengan baik. Sehingga secara keseluruhan menyebabkan lingkungan menjadi kurang bersih dan rapi.

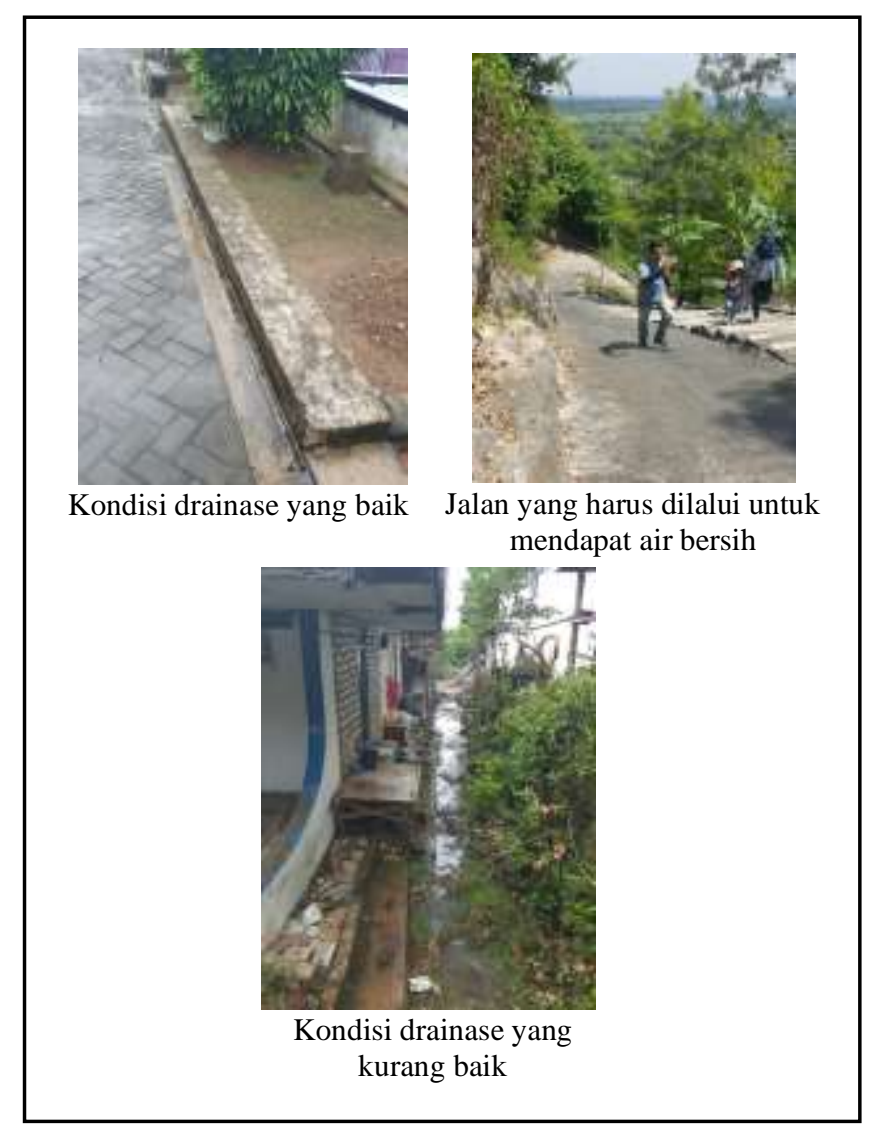

Gambar 5. Kondisi saluran drainase dan jalan di obyek wisata Bukit Surowiti

Pengelolaan sampah di kawasan obyek wisata Bukit Surowiti masih belum terkoordinir dengan baik. Sampah dikelola oleh masing-masing kepala keluarga di Desa Surowiti, namun masih ada sampah yang tidak terambil, seperti sampah rumah tangga dan sampah pengunjung wisata yang ada di makam umum, di sepanjang jalan kawasan wisata.

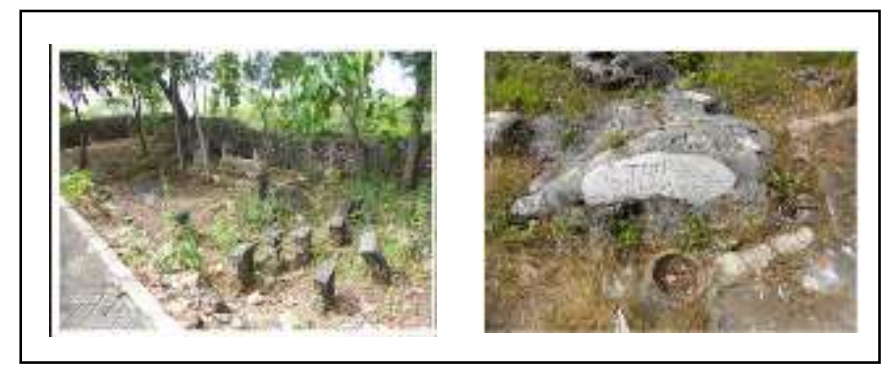

Gambar 6. Kondisi makam umum yang kurang terawat

Kondisi sarana prasarana transportasi juga belum memadai. Transportasi umum seperti bus, khususnya bus pariwisata tidak dapat mencapai lokasi wisata secara langsung, sehingga pengunjung banyak yang tertahan. Berdasarkan studi literatur didapatkan data jumlah pengunjung yang tertahan mencapai \pm 100 orang dalam satu minggu, jumlah ini didapatkan dengan asumsi rata-rata selama seminggu sepeda motor dapat mengangkut 2 orang, kendaraan roda empat 5 orang, dan kendaraan besar seperti bus dapat mengangkut 50 orang (Syafik, 2012).

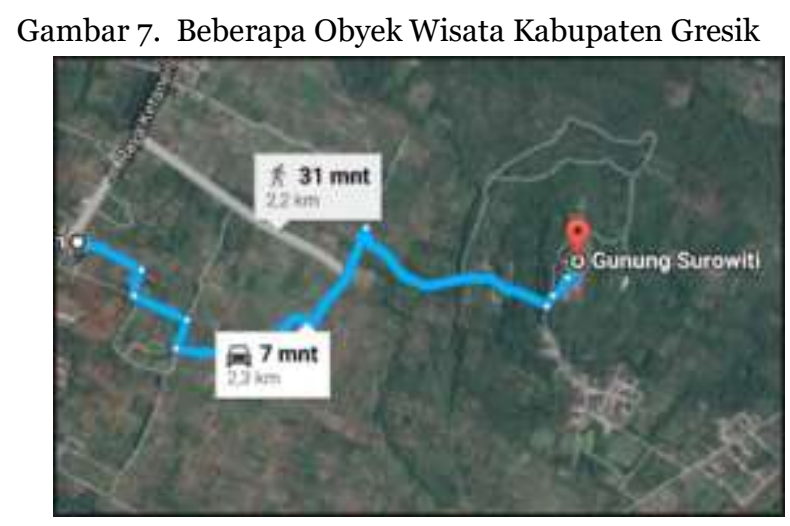

Kelompok Sadar Wisata Desa Surowiti juga menyebutkan bahwa beragam obyek wisata yang ada di Bukit Surowiti belum merata dikunjungi oleh para pengunjung yang datang. Obyek wisata yang paling banyak dikunjungi oleh pengunjung adalah obyek wisata Gua Lingsih, bahkan ada obyek wisata di Bukit Surowiti yang jarang dikunjungi.

\section{Analisis Strategi Faktor Internal dan Eksternal Pengembangan Obyek Wisata Bukit Surowiti di Kecamatan Panceng, Gresik}

Dalam menganalisis strategi faktor internal dan eksternal pengembangan obyek wisata Bukit Surowiti, dilakukan perkalian bobot dan rating. Berikut ini 
Tabel 1. Matriks Faktor Internal Obyek Wisata Religi Bukit Surowiti

\begin{tabular}{|c|c|c|c|c|}
\hline No & Faktor-Faktor Internal & Bobot & Rating & $\begin{array}{l}\text { Skor (Bobot } x \\
\text { Rating) }\end{array}$ \\
\hline \multicolumn{5}{|c|}{ Kekuatan (strength) } \\
\hline $\mathbf{1}$ & $\begin{array}{l}\text { Kawasan wisata religi dengan adanya Petilasan Sunan Kalijaga dan beberapa } \\
\text { makam pemuka agama islam Gresik }\end{array}$ & 0,25 & 3 & 0,75 \\
\hline 2 & $\begin{array}{l}\text { Pemandangan alam di kawasan obyek wisata Bukit Surowiti berupa perbukitan dan } \\
\text { beberapa gua - gua karts }\end{array}$ & 0,23 & 2 & 0,46 \\
\hline 3 & $\begin{array}{l}\text { Menumbuhkan perekonomian bagi penduduk disekitar kawasan obyek wisata religi } \\
\text { Bukit Surowiti }\end{array}$ & 0,11 & 3 & 0,33 \\
\hline \multicolumn{5}{|c|}{ Kelemahan (weakness) } \\
\hline $\mathbf{1}$ & Sulitnya mendapatkan air bersih di kawasan obyek wisata religi Bukit Surowiti & 0,15 & 2 & 0,30 \\
\hline 2 & $\begin{array}{l}\text { Masalah sanitasi atau kebersihan lingkungan yang kurang diperhatikan di kawasan } \\
\text { obyek wisata Bukit Surowiti, seperti drainase dan sampah }\end{array}$ & 0,15 & 2 & 0,30 \\
\hline \multirow[t]{2}{*}{3} & $\begin{array}{l}\text { Kurangnya dana untuk pengembangan sarana dan prasarana pendukung } \\
\text { pengembangan wisata religi Bukit Surowiti }\end{array}$ & 0,11 & 2 & 0,22 \\
\hline & & 1,00 & & 2,36 \\
\hline
\end{tabular}

Tabel 2. Matriks Faktor Eksternal Obyek Wisata Religi Bukit Surowiti

\begin{tabular}{|c|c|c|c|c|}
\hline No & Faktor-Faktor Internal & Bobot & Rating & $\begin{array}{l}\text { Skor (Bobot } \\
\text { x Rating) }\end{array}$ \\
\hline \multicolumn{5}{|c|}{ Peluang (opportunity) } \\
\hline $\mathbf{1}$ & $\begin{array}{l}\text { Kota Gresik sebagai kota santri dan dikenal sebagai kota wisata religi dan wisata wali } \\
\text { di Jawa Timur }\end{array}$ & 0,26 & 3 & 0,78 \\
\hline 2 & $\begin{array}{l}\text { Kondisi obyek wisata disekitar Bukit Surowiti yang sudah dikenal dan menarik banyak } \\
\text { pengunjung, seperti obyek wisata Bukit Jamur dan obyek wisata Pantai Dalegan }\end{array}$ & 0,19 & 2 & 0,38 \\
\hline 3 & $\begin{array}{l}\text { Peran serta masyarakat komunitas Sadar Wisata dalam pengelolaan wisata religi } \\
\text { Bukit Surowiti }\end{array}$ & 0,11 & 3 & 0,33 \\
\hline \multicolumn{5}{|c|}{ Ancaman (Threath) } \\
\hline $\mathbf{1}$ & $\begin{array}{l}\text { Berkembangnya kawasan industri di Gresik dengan semakin luasnya keberadaan } \\
\text { bangunan-bangunan pabrik dari kota menuju pinggiran Kota Gresik }\end{array}$ & 0,20 & 2 & 0,40 \\
\hline 2 & $\begin{array}{l}\text { Perilaku wisatawan yang merubah sarana dan prasarana penunjang di kawasan wisata, } \\
\text { seperti menambahkan tulisan pada pepohonan atau bebatuan, serta perilaku } \\
\text { membuang sampah sembarangan }\end{array}$ & 0,12 & 1 & 0,12 \\
\hline \multirow[t]{2}{*}{3} & Potensi terjadinya longsor atau erosi pada tebing-tebing yang ada & 0,12 & 2 & 0,24 \\
\hline & & $\mathbf{1 , 0 0}$ & & 0,25 \\
\hline
\end{tabular}

Setelah diketahui faktor-faktor internal maupun eksternal yang menjadi kekuatan, peluang, kelemahan dan ancaman bagi pengembangan pengembangan Obyek Wisata Religi Bukit Surowiti maka penentuan strategi dapat dilakukan dengan menggunakan analisis SWOT. Untuk analisis SWOT dari pengembangan Obyek Wisata Religi Bukit Surowiti dapat dilihat di table 3. 
Tabel 3. Matriks SWOT Penentuan Strategi

\section{OPPORTUNITIES}

(O)

1.Kota Gresik sebagai kota santri dan dikenal sebagai kota wisata religi dan wisata wali di Jawa Timur

2.Kondisi obyek wisata disekitar Bukit Surowiti yang sudah dikenal dan menarik banyak pengunjung, seperti obyek wisata Bukit Jamur dan obyek wisata Pantai Dalegan

3.Peran serta masyarakat komunitas Sadar Wisata dalam pengelolaan wisata religi Bukit Surowiti

\section{THREATS}

(T)

1.Berkembangnya kawasan industri di Gresik dengan semakin luasnya keberadaan bangunan-bangunan pabrik sampai ke pinggiran Kota Gresik

2.Perilaku wisatawan yang merubah sarana dan prasarana penunjang di kawasan wisata, seperti menambahkan tulisan pada pepohonan atau bebatuan, serta perilaku membuang sampah sembarangan

3.Potensi terjadinya longsor atau erosi pada tebing-tebing yang ada

Sumber : Hasil Analisis, 2018
STRENGTH

(S)

1. Kawasan wisata religi dengan adanya Petilasan Sunan Kalijaga dan beberapa makam pemuka agama islam Gresik

2.Pemandangan alam di kawasan obyek wisata Bukit Surowiti berupa perbukitan dan beberapa gua -gua karts

3.Menumbuhkan perekonomian bagi penduduk disekitar kawasan obyek wisata religi Bukit Surowiti

WEAKNESS

1.Sulitnya mendapatkan air bersih di kawasan obyek wisata religi Bukit Surowiti

2.Masalah sanitasi atau kebersihan lingkungan yang kurang diperhatikan di kawasan obyek wisata Bukit Surowiti, seperti drainase dan sampah

3.Kurangnya dana untuk pengembangan sarana dan prasarana pendukung pengembangan wisata religi Bukit Surowiti (W-O)

Penguatan konsep wisata religi bagi kawasan wisata Bukit Surowiti $(3,03)$

Meningkatkan partisipasi masyarakat dengan dukungan pemerintah dan swasta dalam pengelolaan obyek wisata religi Bukit Surowiti $(2,31)$

$(\mathrm{W}-\mathrm{T})$

Penerapan regulasi yang tegas kepada pelaku industri di Kabupaten Gresik, dan pengelola wisata maupun pengunjung di kawasan obyek wisata religi Bukit Surowiti $(2,30)$
Perbaikan sarana prasarana penunjang wisata religi di Bukit Surowiti $(1,58)$

Prioritas dari strategi yang dihasilkan dengan memperhatikan faktor-faktor yang saling terkait. Rangking akan ditentukan berdasarkan urutan jumlah skor terbesar hingga terkecil.

Tabel 4. Rangking Strategi Pengembangan Berdasarkan Matriks SWOT

No Alternatif Strategi Keterkaitan Nilai Rangking

\section{Strategi S-O}

1 Penguatan konsep wisata religi di kawasan obyek wisata Bukit $\quad$ S1,S2,S3 $\quad 1,54 \quad$ I Surowiti

$\mathrm{O} 1, \mathrm{O} 2, \mathrm{O} 3 \quad 1,49$

\section{Strategi W-O}

2 Meningkatkan partisipasi masyarakat dengan dukungan $\mathrm{W} 1, \mathrm{~W} 2, \mathrm{~W} 3 \quad 0,82 \quad$ II $\begin{array}{llll}\text { pemerintah dan swasta dalam pengelolaan obyek wisata religi } & 01, \mathrm{O} 2, \mathrm{O} 3 & 1,49\end{array}$

Bukit Surowiti

\section{Strategi S-T}

3 Penerapan regulasi yang tegas kepada pelaku industri di Kabupaten Gresik, dan pengelola wisata maupun pengunjung di $\mathrm{S} 1, \mathrm{~S} 2, \mathrm{~S} 3$ kawasan obyek wisata religi Bukit Surowiti 


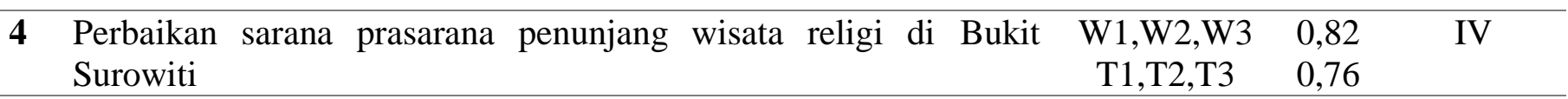

\section{Sumber : Hasil Analisa, 2018}

Dari uraian tabel 1. Sampai tabel 4. dapat diuraikan strategi Pengembangan Obyek Wisata Religi Bukit Suroiti, di Kecamatan Panceng, Gresik adalah sebagai berikut:

a. Penguatan konsep wisata religi di kawasan obyek wisata Bukit Surowiti, Gresik

Kawasan Bukit Surowiti memiliki banyak potensi wisata yang menarik untuk dikunjungi dan dikembangkan lebih serius oleh pemerintah Kabupaten Gresik. Selain untuk melestarikan obyek-obyek wisata peninggalan leluhur yang berupa petilasan dan makam dan pemandangan alam dengan gua-gua karts di Bukit Surowiti, juga sebagai pendukung wisata wali dan wisata alam yang sudah ada di Gresik, serta meningkatkan dan menguatkan perekonomian masyarakat sekitar. Upaya pelestarian obyek-obyek wisata yang ada di kawasan Bukit Surowiti perlu dikembangkan dengan penerapan konsep wisata religi sebagai bagian dari penerapan dan pengembangan wisata halal yang semakin diminati oleh wisatawan lokal maupun mancanegara di Indonesia. Penguatan konsep wisata religi ini membutuhkan kerjasama yang baik antara masyarakat setempat dengan pemerintah Kabupaten Gresik, serta dukungan dari pihak swasta dalam hal ini adalah para pelaku industri di Gresik. Seluruh stakeholders yang ada memiliki peranan penting dalam pengembangan kawasan wisata religi di Bukit Surowiti.

\section{b. Meningkatkan partisipasi masyarakat dalam}

pengelolaan obyek wisata religi Bukit Surowiti

Peningkatan partisipasi masyarakat terutama masyarakat setempat merupakan salah satu pendekatan pengelolaan kawasan wisata yang memerlukan pengetahuan dan kesadaran lingkungan dari masyarakat itu sendiri. Regenerasi yang berkesinambungan dalam pengelolaan obyek wisata yang ada juga diperlukan untuk keberlanjutan pengelolaan obyek wisata religi Bukit Surowiti. Selain itu peran pemerintah sangat dibutuhkan untuk menghindari terjadinya masalah dalam pengelolaan dan pengembangan obyek wisata religi yang ada.

\section{c. Penerapan regulasi yang tegas kepada pelaku} industri di Kabupaten Gresik, dan pengelola wisata maupun pengunjung di kawasan obyek wisata religi Bukit Surowiti

Regulasi yang tegas untuk para pelaku industri dan pengusaha perumahan di Gresik sangat diperlukan untuk membatasi meluasnya pembangunan pabrikpabrik dari sektor industri dan perumahan ke pinggiran kota. Perluasan ini selain akan berakibat berkurangnya potensi wisata yang dimiliki oleh Kabupaten Gresik, juga dapat merusak lingkungan yang ada. Selain itu, regulasi juga dibutuhkan bagi para pengelola serta pengunjung obyek wisata untuk melestarikan lingkungan sekitar kawasan wisata.

\section{d. Perbaikan sarana prasarana penunjang wisata} religi di Bukit Surowiti

Kawasan obyek wisata religi Bukit Surowiti memerlukan perbaikan dan pembangunan sarana prasarana penunjang wisata yang ada di kawasan ini. Kondisi sarana prasarana yang sudah ada masih belum layak dan belum berfungsi dengan baik. Sarana prasarana jalan lingkungan didalam kawasan obyek wisata sudah cukup baik, namun kondisi sarana prasarana lainnya seperti pengadaan air bersih dan sanitasi masih buruk. Perbaikan dan pengembangan sarana dan prasarana tersebut diperlukan untuk mewujudkan kenyaman masyarakat maupun pengunjung obyek wisata, dan menambah daya Tarik dari obyek wisata yang ada.

\section{SIMPULAN DAN SARAN}

\section{Simpulan}

Adapun kesimpulan yang dihasilkan dari penelitian ini adalah sebagai berikut :

a. Perumusan faktor-faktor kekuatan, kelemahan, peluang dan ancaman dalam menentukan strategi pengembangan kawasan wisata religi Bukit Surowiti membantu mendeskripsikan atau memberikan informasi bagaimana kondisi eksisting baik yang potensial dikembangkan maupun yang menjadi hambatan dalam pengembangan dari obyek wisata religi Bukit Surowiti di Kecamatan Panceng, Gresik.

b. Obyek wisata religi Bukit Surowiti merupakan obyek wisata dengan beberapa peninggalan leluhur berupa petilasan dan makam pemuka agama islam. Kawasan Bukit Surowiti dengan wisata religinya bertujuan untuk memenuhi kebutuhan rohani manusia dalam memperkuat iman dengan mendatangi tempat-tempat yang dianggap memiliki nilai religius, sekaligus menikmati keindahan alam diatas bukit terjal Surowiti.

c. Penguatan konsep wisata religi merupakan bagian dari strategi pengembangan kawasan wisata Bukit Surowiti sebagai pendukung wisata wali di Gresik yang dapat meningkatkan perekonomian masyarakat sekitarnya. Penguatan konsep wisata religi ini membutuhkan dukungan dari masyarakat setempat, pemerintah maupun pihak swasta yang ada di Gresik dalam penerapan regulasi pengelolaan obyek wisata maupun pelestarian lingkungan. Selain itu dukungan seluruh stakeholder dibutuhkan untuk meningkatkan sarana prasarana dalam mendukung pengembangan wisata di Bukit Surowiti yang memiliki potensi alam dan peninggalan leluhur yang cukup baik, terutama dalam pengembangan potensi wisata religi.

\section{Saran}

Saran yang dapat diberikan adalah sebagai berikut:

a. Perlu adanya perhatian lebih dari pihak pemerintah dalam mempromosikan Bukit Surowiti sebagai obyek wisata religi yang berpotensi selain obyek- 
obyek wisata alam yang ada di Kecamatan Panceng, Gresik

b. Perlu adanya penelitian lebih lanjut tentang pembangunan sarana prasarana pendukung wisata religi Bukit Surowiti, khususnya sarana prasarana penyediaan air bersih.

\section{DAFTAR RUJUKAN}

[1] Ade, A. R. (2016). Kajian Tentang Potensi Obyek Wisata Bukit Jamur Di Kecamatan Bungah Kabupaten Gresik. Swara Bumi E-Journal Pendidikan Geografi FIS Unesa, 3(3). Retrieved from https:// jurnalmahasiswa. unesa.ac.id/index.php/swara-bhumi/article/view/17166

[2] Anwar, M. F., Hamid, D., Administrasi, F. I., \& Malang, U. B. (2017). Masyarakat Sekitar (Studi pada Kelurahan Gapurosukolilo Kabupaten Gresik). Jurnal Administrasi Bisnis (JAB)|, 44(1), 186-193.

[3] Cetin, G., \& Dincer, M. Z. (2016). Journal of Tourismology, Vol.2, No.1 Muslim friendly tourism (MFT): A discussion Gurel Cetin 1 (Istanbul University) Mithat Zeki Dincer 2 (Istanbul University). Journal of Tourismology, 2(1), 65-67. Retrieved from http://dergipark.gov.tr/download/issue-file/3194

[4] Djakfar, M. (2017). Pariwisata halal. Retrieved from http://repository.uin-malang.ac.id/2422/

[5] Firdausia Hadi and M. Khoirul Hadi al-Asy Ari. (2017). Kajian Potensi Dan Strategi Pengembangan Wisata Pantai Syariah (Studi Di Pulau Santen Kabupaten Banyuwangi). Jurnal Manajemen Dakwah, 3(2), 99-166.

[6] Syafik, M. (2013). Analisis Tentang Aksesibilitas Dan Kunjungan Wisatawan Di Obyek Wisata Bukit Surowiti Kecamatan Panceng Kabupaten Gresik. Swara Bumi EJournal Pendidikan Geografi FIS Unesa, 205-212. Retrieved from https://jurnalmahasiswa.unesa.ac.id/index.php/swarabhumi/article/viewFile/922/682

[7] Widagdyo, K. G., \& Jakarta, U. S. (2015). Analisis Pasar Pariwisata Halal Indonesia, 1(1), 73-80.

[8] Yousaf, S., \& Xiucheng, F. (2018). Halal culinary and tourism marketing strategies on government websites : A preliminary analysis. Tourism Management, 68(February), 423-443. Available at: https://doi.org/10.1016/j.tourman.2018.04.006

[9] Supriharjo, R (2013). Diktat Metodologi Penelitian, ITS Surabaya. 